\title{
The Nature of Leadership Styles of Leaders in Selected Polytechnics in Ghana
}

\author{
Abdul-Razak Abubakari, DBA/PhD \\ Tamale Technical University, Department Of Accountancy
}

\begin{abstract}
This research was conducted on the nature of leadership styles of leaders in selected polytechnics in Ghana. The type of leadership styles and most dominant leadership style among the leaders was to be determined. The Goleman's typology of leadership was adopted. A descriptive survey was conducted on five selected polytechnics sampled from the ten polytechnics. A sample of 214 leaders was drawn from a target population of 461 teaching and non-teaching staff placed on leadership positions in the polytechnics. Means, standard deviations and the Hotelling's t-test was used to analyse the level of significance of the mean averages of the type of leadership styles used by the leaders. The most dominant leadership styles used by the leaders are the; coaching, pacesetting, democratic, and affiliative. The leaders thus need to use the right mix of styles to be able to elicit the work interest of team members to work to realise the strategic goals of the polytechnics. The polytechnics should train leaders on the right mix of leadership styles that would influence all the workers in the polytechnics to work to realise their strategic goals.
\end{abstract}

Key Words: Leadership, leadership styles, Goleman's Leadership typology

\section{Introduction}

In every social setting, like in Polytechnics in Ghana, leadership is observed as a major prerequisite for effective corporate goal attainment. To this end, numerous measures have been adopted by Polytechnics in Ghana to leverage them to realize their strategic mission as they seek to become centres of excellence in teaching and learning in the applied sciences, commerce, and engineering(Polytechnics Act, 745; Tamale Polytechnic, 2013). Boateng (2012) had concluded that leadership should be Ghana's main priority to developing and revitalizing technical education. This is also confirmed by Nanjundeswaraswamy and Swamy (2014) as they posit that today organisations need leaders who understand the complexities of the rapidly changing global environment and if the task is highly structured and the leader has good relationship with the employee, effectiveness will be high on the part of the latter. To Gonos and Gallos (2013) managers, therefore, need to know how to effectively manage; they must select the appropriate style of leadership, but particularly make sure that the enterprise constantly improves on its performance.

Polytechnics in Ghana have over the years adopted strategic leadership as an imperative for effective leadership outcomes. Leadership style of leaders of the Polytechnics will affect their strategic goals. Nahavandi (2002) contends that different leadership styles however affect organisational performance of effectiveness. Jeremy, Melinde, and Ciller (2012) contended that leadership is about influencing team members towards recognizing their full potential in achieving goals, vision, with passion and integrity. Oladipo, Jamilah, Daud, Jeffery and Salami (2013) also alluded that success or failure of proper organisations, nations, and other social units has been largely credited to the nature of their leadership styles. Seshie (2011) emphasized the essence of leadership style and asserted that we can identify interpersonal behaviour and the effects it can have on those being led. It is against this backdrop that this study examines the leadership styles employed by the leaders of the Polytechnics in Ghana.

\subsection{Research Objectives and Questions}

The following research objectives were studied.

i. To determine the leadership styles of leaders in the Ghanaian Polytechnics.

ii. To identify the right leadership styles of leaders in the Ghanaian Polytechnics.

To address the above objectives, the following questions and hypothesis were put.

i. What are the leadership styles of leaders in the Ghanaian Polytechnics?

ii. What are the right leadership styles of leaders in the Ghanaian Polytechnics?

$\mathrm{H}_{1}$ : the dominant leadership style in the Ghanaian polytechnics is the democratic style.

\subsection{Significance of the Study}

This research would add to the stock of knowledge on the typologies of leadership. Hopefully, the body of knowledge of other researchers would be enriched on the subject matter studied. Future researchers would depend on the research report on this study to launch their study on the typologies of leadership. Findings 
realized from the study and recommendations made can be adopted by the polytechnics in Ghana in ensuring that effective leadership will be delivered at all levels of the polytechnics management structure to ensuring that the strategic goals of these institutions are realized.

\subsection{Research Design}

A descriptive survey was conducted and the population of the study was all the staff (both teaching and non-teaching with administrative responsibilities) in all the ten Polytechnics in Ghana. The target population however wasteaching and non-teaching staff who were placed at functional leadership positions in Tamale, Koforidua, Sunyani, Bolgatanga, and Kumasi Polytechnics. These five polytechnics were chosen from the total of through simple random sampling. A survey was conducted to gather data on the respondents' leadership styles. This is in line with Trottier et al. (2008) contention that in a survey, questions cover a wide array of issues. The staff who met the inclusion criteria (staff with more than three month experience in leadership) were then made to answer the questionnaires. Means and standard deviations associated with means was used to explain the variance of the data from the means and the Hotelling's T Test was used in analyzing the level of significance of the means averages of the types of leadership styles of the respondents. The total number of staff in leadership position of the selected polytechnics studied were 461 and from this a sample size of 214 was drawn using the Taro Yamane's (1973) sample size formula with an error margin of 5 per cent: $n=N /\{1+N$ (a) $\}^{2}$ Where $\mathrm{n}$ is the sample size, $\mathrm{N}$ is the population size, and ' $\mathrm{a}$ ' is the error margin.

\section{Literature Review}

There is existing knowledge that leadership is a fundamental requirement for the realization of the strategic goals of every organization. This is because no business can run successfully without effective leaders among other factors. Thus is corroborated by Juras (2010) as he contended that organizations require a special organization resource such as an effective leader, who will with his or her special traits, developed skills and appropriate leadership styles, strongly and honestly lead the organization. Leadership had been variedly defined by authors. Mujtaba and Isomura (2012) defined leadership as a function consisting of at least three complex variables: tleader, the followers, and situational conditions, and leadership means an infinite number of possible combinations. Van Vector (2012) also posited that leadership is both a science and an art of influencing others; and a leader is anyone who inspires others to accomplish organizational goals. Robbins and Coulter (2009) on the other hand contended that a leader is someone who can influence others and at the same time has managerial authority; leadership is what leaders do. Other researchers (Buchanan and Huczynski, 2004; Yukl, 2006; Keitner and Kinicki, 2010) put it that leadership is a social process of influencing others to voluntarily participate in achieving organizational goals. Nastase and Barbu (2011) introduced a new approach of leadership defining it through "leadership mix". The variables used in their definition are: knowledge, brain competence and social competence. These three, according to them, lead to a mix of leadership composed of flexibility, followers, force and fairness, facilitator and feelings' intelligence.

What is clear about all these definitions is that leadership has to do with: team spirit; goal orientation; ability to influence team members towards a goal attainment; and the ability to determine, understand and manage the feelings of team members towards the attainment of a group goal - this can be a strategic business goal. Leadership may be able to exert the influence on the team members to attain the team goals when the members are led with team knowledge, brain competence and social competence. This is what Nastase and Barbu (2011) referred to as leadership mix. Leaders' behavior patterns influence their relation with stakeholders of the organisation and these patterns of behavior influences performance. Al-Kahtani et al. (2011) defined the word "style" as a pattern of regularities in the act of leading. Biggerstaff (2012) defined leadership style as the perceived behavior patterns that a person exhibits when attempting to influence the activities of others. Many authors however have agreed that a leader's style varies according to his personality, environment, education, training and personal philosophy (Hughes et al., 1999; Clark et al., 2009). To be successful, leaders need a behavioral repertoire and have the ability to select the right role for the situation (Leban \& Zulauf, 2004).

\section{Leadership Typologies}

Voegtlin et al. (2012) proposed that successful leader is more effective in building good and robust relations with stakeholders and can make the required organizational change especially in structure and culture with minimum resistance. Al-Khasawneh and Futah (2013) have then concluded that leadership has direct and indirect effects on organizational performance. It therefore requires an appropriate leadership style to be adopted at the right time given the leadership situation to address a given performance goal. To Tangpinyoputtikhhun and Tiparos (2011), the leadership literature has rich typologies. Also, over the last seventy years, there has been six main schools of leadership theory (Handy, 1982; Dulewicz and Higgs, 2003). They put out: the traits school; the behavioral or style school; the contingency school; the visionary or charismatic school; emotional intelligence school; and the competency school. As opposed to traits approach, which focuses on the 
characteristics of the personality, and to the skills approach which emphasizes leader's ability, the style approach takes into consideration leaders' behaviour (Juras, 2010). There is research evidence on the behavior of leaders especially into the styles of leadership that influence organizational performance (Juras, 2010; Salman, Riaz, Saifulla \& Rashid, 2011; Khan, Hafeez \& Rizvi, 2012, Goleman, 2000). These theories proposed that there are set of behaviors through which leaders are distinguished from non-leaders.

Kurt Lewin and associates conducted studies at the University of Iowa that concentrated on the leadership styles of managers (Lewin, Lippitt \& White, 1939). Yang, Chang and Johnson (2009) contended that the Iowa studies contributed to the behavioral movement and led to an era of behavioral rather than trait research. Also, the University of Michigan Survey Research Centre under the guide of Rensis Likert conducted studies to determine how leaders functioned in small groups (Achua \& Lussier, 2013). Likert (1961), the researchers' goals were to; classify the leaders as effective and ineffective by comparing the behaviour of leaders from high-producing units and low-producing units; and determine the reasons for effective leadership. Achua and Lussier (2013) contended that the Likert led research identified two (2) styles of leadership: jobcentered and employee centered and further describe these styles as one dimensional continuum with between two leadership styles. Achua and Lussier (2013) asserted that the Iowa studies identified two basic leadership styles: autocratic and democratic leadership styles.

Stogdill and Coons (1957) conducted a study to determine effective leadership styles. In a bid to measure leadership styles, these researchers developed an instrument known as the Leader Behaviour Description Questionnaire (LBDQ). To Al-Khasawneh and Futa (2013), the survey measured leadership styles in two dimensions: consideration and initiating structure. Consideration had to do with mutual respect, support, and friendship between leaders and followers are the leadership behaviour indicators. Also, Achua and Lussier (2013) put it that the consideration leadership style is essentially the same as the employee centered leadership style; it focuses on meeting people's needs and developing relationships. The Goleman (1998) typology would be adopted as a framework for the study of leadership styles and their effects on effective strategic leadership. In his celebrated article on "Leadership that gets Results" Goleman (2000), he typified six leadership styles: Coercive, Authoritative, Affiliative, Democratic, Pacesetting and Coaching.

\section{Goleman's leadership styles}

Leaders' singular job is to get results (Goleman, 2000). Realizing these results depends on several factors and leadership style is one of these factors. To Goleman, a random sample of 3871 executives selected from the database of a consulting firm Hay/McBer takes much mystery out of effective leadership. The research found six distinct leadership styles, each springing from different components of emotional intelligence. The Six leadership styles identified were: coercive, authoritative, affiliative, democratic, pacesetting and coaching. This research explores the leadership styles of leaders of the Ghanaian Polytechnics based on the Goleman's typology of leadership.

\section{The coercive style}

To Xie et al. (2011), the coercive leader has clear perception and requires their employees to do what they are exactly told. Thus, the leader's extreme top-down decision making skills put new ideas on the vine (Goleman, 2000). The people feel so disrespected that they think "I won't even bring my ideas up-they'll only be shot down". The coercive styles also has the damaging effect on the reward system that most highperforming workers are motivated by more than money-they seek the satisfaction of work well done. More so, Goleman (2000) posited that the coercive style undermines one of the leader's prime tools-motivating people by showing them how their job fits into a grand shared mission. Such a loss, measured in terms of diminished clarity and commitment, leaves people alienated from their own jobs. To Goleman, the coercive style is the least effective among all the six styles as applied in most situations.

\section{The authoritative style}

The authoritative leader makes sure that the mission statement is built into the company's strategic planning process as the designated driver of growth (Goleman, 2000). Therefore, the authoritative leader is visionary; he motivates people by making clear to them how work fit into larger vision for the organization. The authoritative leader also maximizes commitment to the organization's goals and strategy. Goleman (2000) contended that an authoritative leader states the end but generally gives people plenty leverage (leeway) to devise their own means. To Xie et al. (2011), the authoritative leader gives people the freedom to innovate, experiment, and take calculated risk. An authoritative leader is a confident person, an expert with clear perceptions of what exactly needs to be done to achieve a goal. This means that an authoritative leader values the initiative of team members towards the attainment of corporate goals and the posturing of the authoritative leader gives room for flexibility and thereby creates ample opportunity for the injecting of innovative ideas. 


\section{Affiliative leadership style}

This style revolves around people-its proponents value individuals and their emotions more than risk and goals (Goleman, 2000). Usually, the affiliative leaders keep their employees happy, develop team trust, and create harmony among them (Xie et al., 2011). The leader gives people the freedom to do their job in the way they think is most effective. This kind of leaders are masters of building a sense of belonging. The Affiliative style's generally positive impact makes it a good all-weather approach, but leaders should employ it particularly when trying to build team harmony; increase morale; improve communication or repair broken trust (Goleman, 2000). Goleman advocated that despite its benefits, the affiliative style should not be used alone. That its exclusive focus on praise can allow poor performance to go uncorrected, employees may perceive that mediocrity is tolerated. This suggests that despite the underlying essence of leadership being to generate desired results, it is encumbered on the leader to influence the direction of employees' performance towards the collective goal attainment.

\section{Democratic leadership style}

The democratic leader according to Xie et al. (2011) asks employees to participate in the decision making process but maintain the final decision. By letting the workers themselves have a say in decisions that affect their goals and how they do their work, the democratic leader drives up flexibility and responsibility (Goleman, 2000). Listening to employees' concerns, the democratic leader learns what to do to keep morale high and because they have a say in setting their goals and the standards for evaluating success, people operating in democratic system tend to be very realistic about what can and cannot be accomplished (Goleman, 2000). The democratic style, of course, makes much less sense when employees are not competent or informed enough to offer sound advice. Also Goleman asserted that one of its more exasperating consequences can be endless meetings where ideas are mulled over, consensus remains elusive, and the only visible result is scheduling more meeting.

\section{Pacesetting style of leadership}

According to Goleman (2000), with pacesetting style "the leader sets extremely high performance standards and exemplifies them himself. He is obsessive about doing things better and faster, and he asks the same of everyone around him. He quickly pinpoints poor performance and demands more from them" (p.86). Goleman further asserted that the pacesetting style destroys climate. Many employees feel overwhelmed by the pacesetter's demands for excellence, and their morale drops. Also, that guidelines may be clear in the leader's head, but she does not state them clearly; she expects people to know what to do and even thinks "if I have to tell you, you were the wrong person for the job". More so, flexibility and responsibility evaporates; work becomes so task-focused and routinized and gets boring. Goleman concluded that the approach works well when employees are self-motivated, highly competent, and need direction or coordination.

\section{Coaching leadership style}

Coaching leaders, according to Goleman (2000), "help employees identify their unique strengths and weaknesses and tie them to their personal and career aspirations" (p.87). Goleman further posits that coaching leaders excel at delegating, they give employees challenging assignments, even if that means the task won't be accomplished quickly. In other words, this leaders, to Goleman (2000) are willing to put up with short-term failure if it furthers long term learning. Goleman (2000) has admitted that there is a paradox in coaching's positive effect on business performance because coaching focuses primarily on personnel development, not on immediate work related tasks. On the contrary, the coaching style makes little sense when employees, for whatever reason, are resistant to learning or changing their ways.

\section{The Right Mix of Leadership Styles}

Seldom will a leader employ only one leadership style to be able to achieve any management or leadership goal. Hersey, Blanchard, and Johnson (2009) posited that there is no "one best way" of leadership and the most successful leaders adjust their leadership style to the maturity of the individual or the group and also to the task which is to be performed. On this premise, Goleman (2000) concluded that leaders who have mastered four or more-especially the autocratic, democratic, democratic, affiliative, and coaching styles, have the very best climate and business performance. He further put it that "such leaders do not match their style to fit a checklist of situation, they are far more fluid" (p.87). The most effective leader or the most effective executives use a collection of distinct styles-each in the right measure, at just the right time. Such flexibility is tough to put in action, but it pays off in performance. And better yet, it can be learned (ibid). Goleman (2000) further argued that in turbulent times effective leaders need to: demand immediate compliance with coercive leadership style; mobilize people toward a vision with an authoritative leadership style; create harmony and build emotions with an Affiliative leadership style; forge consensus through participation with a democratic 
leadership style; set high standards for performance with a pacesetting style; and develop people for the future with the coaching style.

\section{Sample Demographics}

Of the 180 questionnaire retrieved, about $75 \%$ of the respondents were noted to have attained master's degree, $6 \%$ had $\mathrm{PhD}$ or doctorate and about 5\% had diploma certificate. This suggests that the respondents had a very high profile of academic attainment and may easily appreciate the need for the delivery of strategic goals of the polytechnics.

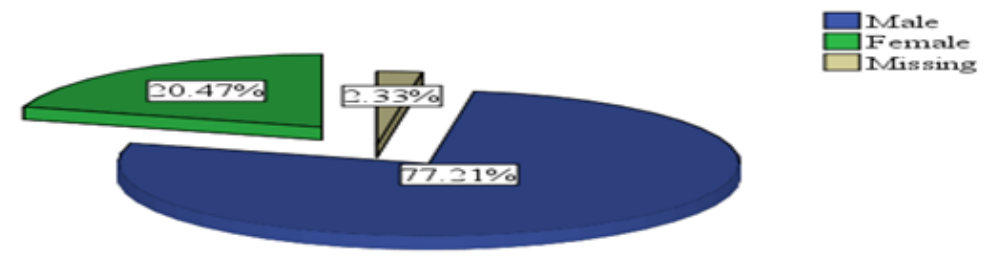

Figure 1. Gender Distribution of Respondents

Source: Field Survey, March 2014

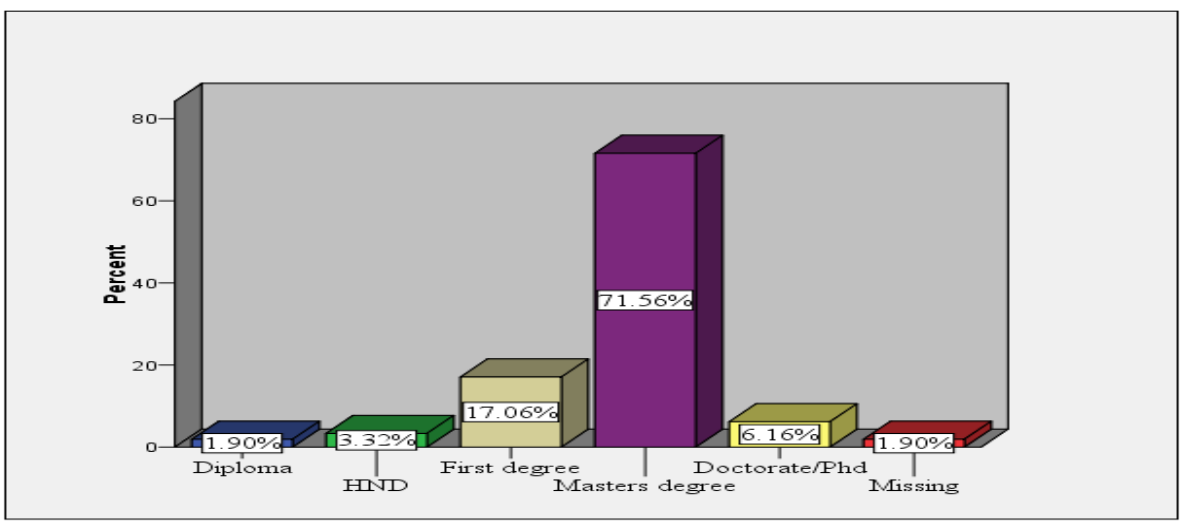

Figure 2. Educational Attainment of respondents (Source: Field Survey, March 2014)

The respondents who were exclusively placed as administrators were $55 \%$ and those who were placed at teacher leadership responsibility were about $45 \%$. This suggests that the survey had a balanced representation of administrative staff and teachers placed at leadership responsibilities.

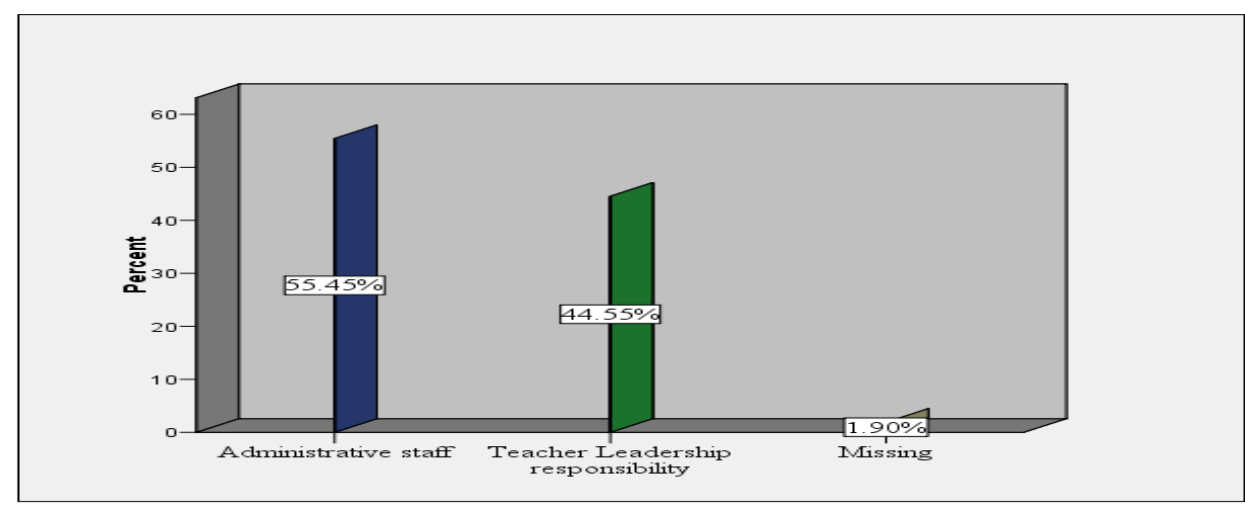

Figure 3. Job Placements of Respondents

Source: Field Survey, March 2014

\section{Leadership Styles of Respondents}

Objective one of the research sought to determine leadership styles of the respondents in the Ghanaian polytechnics studied. To realise this objective, a research question: what are the leadership styles of leaders in the Ghanaian polytechnics? was studied and a related hypothesis $\left({ }_{1} \mathrm{H}_{1}\right)$ the dominant leadership style in the polytechnics is the democratic leadership were researched on. 


\section{Leadership Style of Respondents}

In a bid to realise the research objective one, "to determine the leadership styles of the leaders of the polytechnics", the researcher studied the respondents in terms of their application of the various leadership styles typified by Goleman (2000).Also, this section is expected to answer the research question one "what are the leadership styles of respondents"? And therefore the hypothesis one $\mathbf{H}_{0}$ that: the dominant leadership style in the polytechnics is the democratic style will be confirmed or otherwise. Table 1 presents data on the coercive leadership style of respondents. This type of leadership had a total sample average response of 3.6. Respondents were asked to rate five statements on a five point Likert's scale and the statements 'I have drive and initiative to achieve results (4.29)', 'I always employ this when I am in crises (3.60)' had their means equal or above the sample average of 3.6. Other statements such as 'I often demand immediate compliance (3.37)', 'I require team members to do what I tell them (3.44)' had their averages below the sample mean average of 3.6. Table 1 also shows that the data on coercive leadership style has a reliability coefficient of 0.813 and the Hotelling's TSquared test proves that response to the statement is very significant. The response pattern on Table 1 implies that Xie et al. (2011) assertion that the coercive leader has a clear perception and requires their employees to do what they are exactly told is not conformed. Also, the fact that Goleman (2000) contended that the coercive is the least effective among all the styles applied in most situations is confirmed by the pattern of this response on Table 1.

Table 1:The Coercive Leadership Style of Respondents



Source: Field Survey, March 2014

Table 2 presents data on the pacesetting leadership style of respondents. The sample mean

Table 2: Pacesetting Leadership Style of Respondents

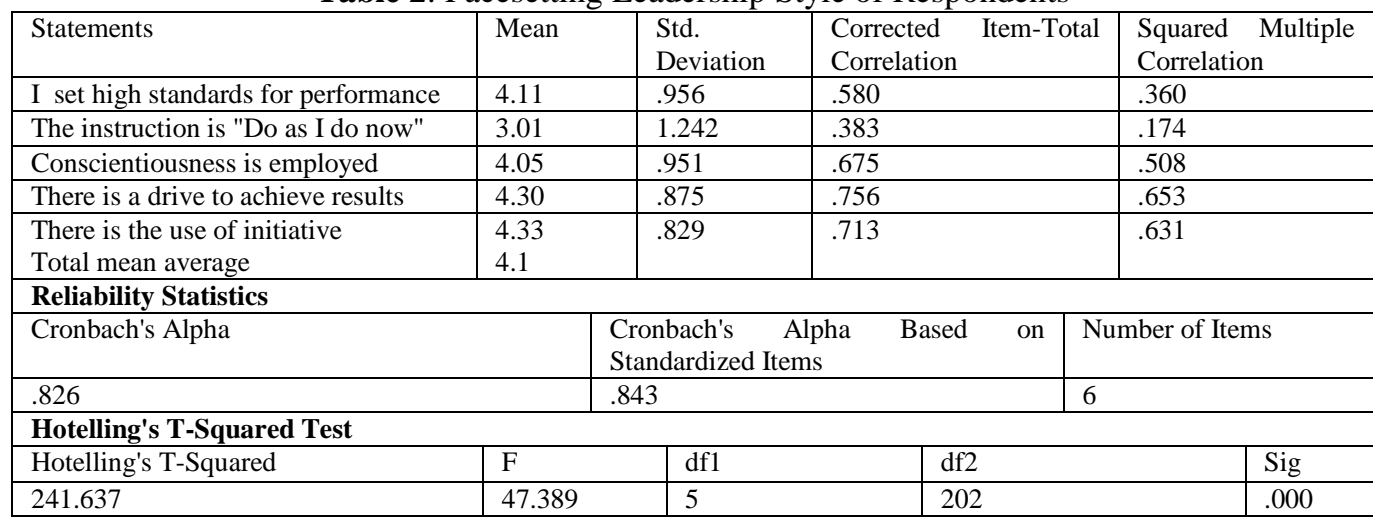

Source: Field Survey, March 2014

Average is shown as 4.1 and the statements 'I set high standards for performance (4.11)', 'there is a drive to achieve results (4.30)' and 'there is use of initiative (4.33)' recorded means of above the 4.1 average for the pacesetting leadership style. A reliability coefficient of 0.826 illustrated on Table 2 suggests the data is very reliable and the Hotelling's' T-Squared test gave a result that the data on pacesetting leadership style give very significant results. Therefore, Goleman (2000) assertion that with pacesetting style the leader sets extremely high performance standards and exemplifies them himself is confirmed. The authoritative leadership style recorded a mean average of responses of 3.9. Responses to statement 'I mobilise people towards a vision (4.20)', 'self-confidence is usually required (4.32) and 'change catalyst is required (3.95)' had their means above the mean average of 3.9. 'Empathy is required' however recorded a mean below the 3.9 average. A reliability coefficient of 0.737 implies the data on pacesetting is very reliable and the Hotelling's T-Squired 
Table 3: Authoritative Leadership Style of Respondents

\begin{tabular}{|c|c|c|c|c|}
\hline Statements & Mean & Std. Deviation & $\begin{array}{l}\text { Corrected Item- } \\
\text { Total } \\
\text { Correlation }\end{array}$ & $\begin{array}{l}\text { Squared Multiple } \\
\text { Correlation }\end{array}$ \\
\hline I mobilize people towards a vision & 4.20 & .952 & .621 & .489 \\
\hline The instruction usually comes from me & 3.47 & 1.105 & .307 & .216 \\
\hline Self-confidence is usually required & 4.32 & .761 & .692 & .536 \\
\hline Empathy is required & 3.80 & 1.108 & .382 & .333 \\
\hline $\begin{array}{l}\text { Change catalyst is required } \\
\text { Total mean average }\end{array}$ & $\begin{array}{l}3.95 \\
3.9\end{array}$ & .944 & .611 & .428 \\
\hline \multicolumn{5}{|l|}{ Reliability Statistics } \\
\hline Cronbach's Alpha & \multicolumn{3}{|c|}{ Cronbach's Alpha Based on Standardized Items } & Number of Items \\
\hline .737 & .761 & & & 5 \\
\hline \multicolumn{5}{|l|}{ Hotelling's T-Squared Test } \\
\hline Hotelling's T-Squared & $\mathrm{F}$ & df1 & & Sig \\
\hline 190.083 & 46.829 & 4 & $\frac{\mathrm{df} 2}{203}$ & .000 \\
\hline
\end{tabular}

Source: Field Survey, March 2014

Test conducted gave a very high significant results as illustrated on Table 3. Thus, Goleman's (2000) contention that with a vibrant commitment and clear vision, the authoritative leader makes sure that the mission statement is built into the company's strategic planning process as the designated driver of growth is confirmed. The affiliative style has the response mean of 4.2 and statements 'I create harmony (4.43)' and 'building relationship makes it work (4.34)' had their averages almost close to the sample response mean average. A Cronbach's alpha of 0.877 suggests that the data on these responses are very reliable and the Hotelling's TSquare test also presents the data as being very significant. This outcome confirms Xie et al (2011) conclusion that the affiliative leaders keep their employees happy, develop team trust and create harmony among them.

Table 4: Affiliative Leadership Style of Respondents

\begin{tabular}{|c|c|c|c|c|}
\hline Statements & Mean & $\begin{array}{l}\text { Std. } \\
\text { Deviation }\end{array}$ & $\begin{array}{l}\text { Corrected Item-Total } \\
\text { Correlation }\end{array}$ & $\begin{array}{l}\text { Squared Multiple } \\
\text { Correlation }\end{array}$ \\
\hline I Create harmony & 4.43 & .805 & .731 & .609 \\
\hline I build emotional bonds & 4.12 & .854 & .656 & .504 \\
\hline I tell colleagues "People come first" & 4.16 & .899 & .616 & .481 \\
\hline Empathy is employed & 4.14 & .827 & .639 & .446 \\
\hline $\begin{array}{l}\text { Building relationships make it work } \\
\text { Total mean average }\end{array}$ & $\begin{array}{l}4.34 \\
4.20\end{array}$ & .811 & .761 & .628 \\
\hline \multicolumn{5}{|l|}{ Reliability Statistics } \\
\hline Cronbach's Alpha & \multicolumn{3}{|c|}{ Cronbach's Alpha Based on Standardized Items } & Number of Items \\
\hline .877 & \multicolumn{2}{|c|}{.882} & & 7 \\
\hline \multicolumn{5}{|l|}{ Hotelling's T-Squared Test } \\
\hline Hotelling's T-Squared & \multicolumn{2}{|l|}{$\mathrm{F}$} & df1 & Sig \\
\hline 107.424 & 17.454 & 6 & 194 & .000 \\
\hline
\end{tabular}

Source: Field Survey, March 2014

The democratic leadership style had a response mean average of 4.3 with statements 'I usually ask "what do you think" (4.34)', 'collaboration is employed (4.50)', and 'effective communication is employed (4.59)' scoring above the responses mean average of 4.3. Also the response 'I forge consensus through participation (4.25)' had an average close to the total response mean average. These statements also have a strong corrected item-total correlation implying that they have strong influence in the set of data on the democratic leadership style. A reliability coefficient of 0.847 and the Hotelling's T-Square test present a reason to conclude that the data is very significant. Therefore Goleman's (2000) assertion that by letting the workers themselves have a say in decision that affect their goals and how they do their work that the democratic leader drives up flexibility and responsibility is confirmed.

Table 5: Democratic Leadership Style of Respondents

\begin{tabular}{|c|c|c|c|c|c|c|}
\hline \multicolumn{2}{|l|}{ Statements } & Mean & $\begin{array}{l}\text { Std. } \\
\text { Deviation }\end{array}$ & $\begin{array}{l}\text { Corrected Item-Total } \\
\text { Correlation }\end{array}$ & $\begin{array}{l}\text { Squared } \\
\text { Correlation }\end{array}$ & Multiple \\
\hline \multicolumn{2}{|l|}{ I forge consensus through participation } & 4.25 & 1.027 & .612 & .424 & \\
\hline \multicolumn{2}{|l|}{ I usually ask "What do you think?" } & 4.34 & .862 & .706 & .513 & \\
\hline \multicolumn{2}{|l|}{ There is to team leadership } & 4.22 & .981 & .578 & .357 & \\
\hline \multicolumn{2}{|l|}{ Effective communication is employed } & $\begin{array}{l}4.59 \\
4.30 \\
\end{array}$ & .758 & .708 & .562 & \\
\hline \multicolumn{2}{|l|}{ Cronbach's Alpha } & \multicolumn{3}{|c|}{ Cronbach's Alpha Based on Standardized Items } & \multicolumn{2}{|l|}{ Number of Items } \\
\hline \multicolumn{2}{|l|}{.847} & .857 & & & 5 & \\
\hline \multicolumn{7}{|l|}{ Hotelling's T-Squared Test } \\
\hline Hotelling's T-Squared & \multicolumn{2}{|l|}{$\mathrm{F}$} & df1 & \multicolumn{2}{|l|}{ df2 } & Sig \\
\hline 55.818 & \multicolumn{2}{|l|}{13.750} & 4 & \multicolumn{2}{|l|}{202} & .000 \\
\hline
\end{tabular}

Source: Field Survey, March 2014 
The last style of leadership studied is the coaching style and Table 5 illustrates data on it. Data on Table 5 shows that the total responses on the coaching style had a mean average of 4.3 and all statements but ' $I$ employ empathy (4.18)' have means above the average mean score of the responses. The responses 'I develop people for future (4.43)', 'I facilitate learning by suggesting 'try this" (4.36)', 'the interest is to develop others (4.48)' are the important coaching styles provisions that respondents use to facilitate team members development. The data presented in Table 5 had a reliability coefficient of 0.861 and the Hotelling's T-Square test suggested that the data is very significantly related to the sample average recorded. Thus, Goleman (2000) assertion that coaching has positive effect on business performance because coaching focuses primary on personal development is confirmed.

Table 6: Coaching Leadership Style of Respondents

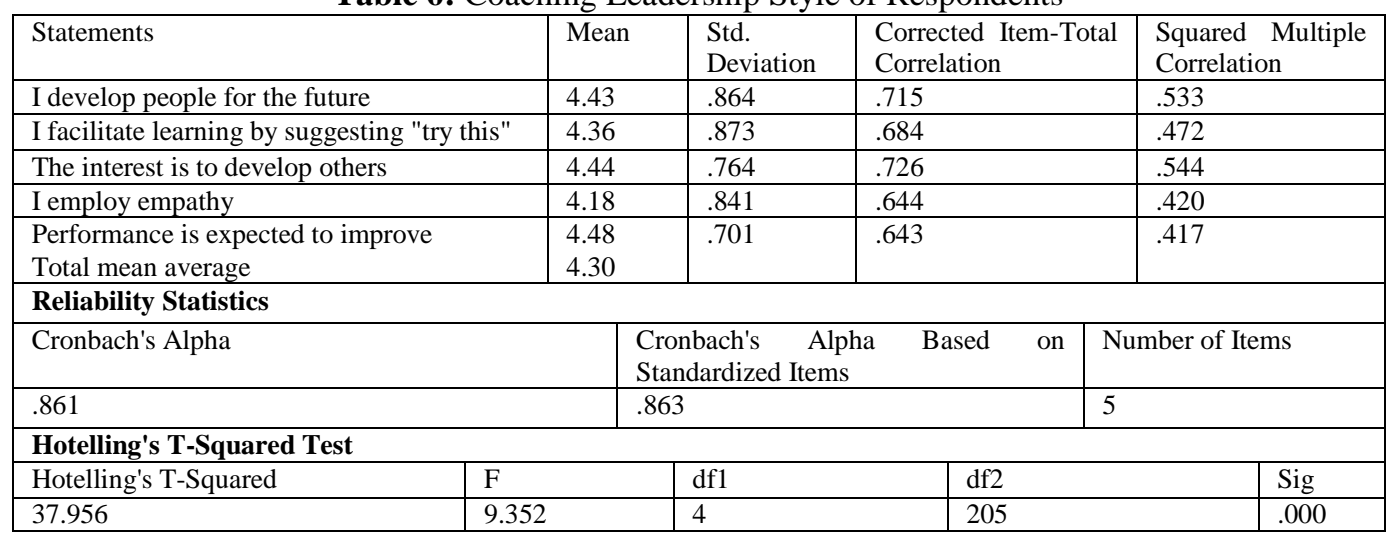

Source: Field Survey, March 2014

Respondents were asked which of the leadership style is most used. In response to the question, 37\%, $24 \%, 15 \%$ and about $12 \%$ chose democratic, coaching, pacesetting and affiliative leadership styles respectively. Reference to Table 2, the pacesetting leadership style had a sample mean average of 4.1, the affiliative style in Table 3 had 4.2, the Democratic style in Table 4 had 4.3 and Coaching style in Table 6 had 4.3 sample mean average as well and all these styles have their reliability coefficients above 0.8 and their individual Hotelling's $\mathrm{T}$-Squared test have all proven that the responses are very significantly related to the sample average means. Therefore in reference to objective one of this study, the dominant leadership styles that respondents apply most are the democratic, coaching, pacesetting and affiliative styles. Also in answering the research questions ${ }_{1} R_{1}$ what are the leadership traits and leadership styles of leaders of the polytechnics, the democratic, coaching, pacesetting and affiliative styles are the most used. Also, the hypothesis $1\left({ }_{1} \mathrm{H}_{1}\right)$ that: the dominant leadership style in the polytechnics is the democratic style is validated but with other styles such as pacesetting, affiliative, and coaching styles featuring equally prominently. Thus, Hersey et al. assertion that there is no one "best way" of leadership and the most successful leaders adjust their leadership style to the maturity of the individual or the group and also task to be performed is confirmed.

Table 7: Determination of Respondents' Best Leadership Styles

\begin{tabular}{|l|l|l|l|}
\hline \multirow{2}{*}{ Leadership Traits } & Responses & \multirow{2}{*}{ Percent of Cases } \\
\cline { 2 - 4 } & $\mathrm{N}$ & Percent & \\
\hline Coercive & 23 & $5.6 \%$ & $11.3 \%$ \\
\hline Authoritative & 25 & $6.1 \%$ & $12.3 \%$ \\
\hline Affirmative & 49 & $11.9 \%$ & $24.1 \%$ \\
\hline Pacesetting & 63 & $15.3 \%$ & $31.0 \%$ \\
\hline Coaching & 99 & $24.0 \%$ & $48.8 \%$ \\
\hline Democratic & 154 & $37.3 \%$ & $75.9 \%$ \\
\hline Total & 413 & $100.0 \%$ & $203.4 \%$ \\
\hline \multicolumn{2}{|l}{} \\
\hline
\end{tabular}

\section{Discussion}

\section{Frequency Analysis and the Hotelling's t-squared tests on hypothesis 1: $\mathbf{H}_{1}$.}

For objective one of the study, frequencies were employed in the analysis of the data. Mean averages of the various leadership styles were employed to determine the level of predominance of a style or trait among the leaders studied. Objective one of the research sought to determine the leadership styles of the leaders in the polytechnics in the Ghanaian. To answer the question, "what are the leadership styles of leaders in the polytechnics in the Ghanaian? A hypothesis $\mathbf{H}_{\mathbf{1}}$ : the dominant leadership style in the Ghanaian polytechnics is the democratic style was cast. Each leadership style had a number of statements to which respondents were ask to rate and therefore the means of these responses were taken and for each leadership style an average of the 
mean (mean of their means) was taken. The mean of means of each leadership style was compared to the other and the one with the greatest average was considered the most dominant. The dominant leadership trait was determined in the like manner. To confirm the level of significance of the data realized from the frequencies of the leadership styles, the Hotelling's T-Squared test was conducted. For frequency to be considered significant, the Hotelling's T-Squared test was expected less than 0.05. Frequency analysis (Tables 1, 2, 3, 4, 5, and 6) present data on the coercive, pacesetting, authoritative, affiliative, democratic, and coaching styles of leadership. Each of the tables on the leadership style presented the frequencies of the respective mean of each style of leadership. Also, Hotelling's T-Squared test is used to determine the level of significance of the data under each style and the Cronbach's alpha coefficient is used to present the reliability coefficient of the data under each style of leadership. The coercive leadership style has a sample response average of 3.6 (See Table 1) with a very high significance level shown from the Hotelling's T-Squared test, $\mathrm{p}=.000$, with a reliability coefficient of .813 . Pacesetting had a response average of 4.1, a reliability coefficient of 0.826 and the Hotelling's T-Squared test with a very high significance level, $\mathrm{p}=0.000$. The authoritative style had a response average of 3.9, a reliability coefficient of .737 with a very significant level from the Hotelling's T-Squared test of $p=0.000$. Also, the affiliative style had a response mean average of 4.2, a reliability coefficient level of the Hotelling's T-Squared test of $p=0.000$. The democratic leadership style on the other hand had a response average of 4.3 , a reliability coefficient of 0.847 and a very high Hotelling's T-Squared test significance level of $\mathrm{p}=0.000$. The coaching leadership style had a mean average of 4.3 with a very high level of significance shown from the Hotelling's TSquared test of $p=0.000$ and a reliability coefficient of 0.861 . Reference to (Table 2, 3, 4, and 5) it is noted that the pacesetting had a sample average of 4.1, affiliative (4.2), democratic (4.3) and coaching (4.3) respectively with their reliability coefficients above 0.8 with equally very high significance level results from the Hotelling's T-Squared test.

Therefore, the conclusion is that the dominant leadership style that the respondents apply mostly in the polytechnics are the: democratic, coaching, pacesetting and affiliative styles. The hypothesis $1\left({ }_{1} \mathrm{H}_{1}\right)$ that: the dominant leadership style in the Ghanaian polytechnics is the democratic style is confirmed. Other styles such as pacesetting, affiliative and coaching styles also feature prominently. To round up, in answering the research question 1 what are the leadership styles of leaders of the Ghanaian polytechnics, the democratic, coaching, pacesetting, affiliative, and coaching styles are the most used. From the above, leaders in the polytechnics need to accept the increasing reality that democracy is a tenable means for teams, groups and societies to appreciate their growth and development goals. The choice of democratic leadership as a dominant style among the respondents suggests that decisions on what measures need be adopted for the realization of the strategic goals of the polytechnic need be determined in a participatory manner. Leadership among the staff of the polytechnics need to understand that decisions on what to do and how to do that must be collectively made. This will be a means of carrying all and sundry along the process of the strategic goals achievement. The fact that other types of leadership such as affiliative, coaching, and pacesetting also feature prominently implies that leaders are not supposed to be inclined to one style of leadership in the polytechnics. For, Goleman (2000) concluded that the business environment is continually changing, and a leader must respond in kind. That hour to hour, day to day, week to week, executives must play their leaders styles like a pro-using the right one at just the right time measure. The payoff, to Goleman (2000), will be the results. Ramkissoon (2009) has also supported the Goleman's conclusion on the choice of leadership styles and concluded in a study that overall, the findings of the past studies show that situational leadership has some applicability in non-Western cultures and provides support for the utility of the theory. That is why Juras (2010) concluded on his study of traits, skills leadership and leadership styles of managers of Croatian firms that regardless of the leadership approach preferences ( traits approach, skills approach or style approach), it is impossible to deny the impact of each of these approaches on effective leadership development. The Juras (2010), Goleman (2000), and Ramkissoon's (2009) conclusions on the choice of leadership styles should guide leaders in the Ghanaian polytechnics in their choice and application leadership styles.

\section{Conclusion}

It was established that the dominant styles adopted by the leaders are the: coaching, pacesetting, democratic, and the affiliative leadership styles. It does requires all the leaders in the polytechnics to be mindful about the appropriate styles they need to adopt to ensure the ability to exude interest from the team members to work towards the realization of the strategic goals of the polytechnics. The leaders should therefore be mindful about the situations they are exposed to and adopt the right mix of leadership styles to be able to elicit the work interest of the team members towards the realization of the strategic leader outcomes of the polytechnics. For, style should not be an individual's choice but what the situation of or the job demands. The leadership styles should be carefully chosen to ensure that they are aligned to the strategic leadership outcomes of the polytechnics. This can be made possible when the policy makers ensure that they train the leaders on the need 
for the right blend of leadership that need be adopted for the realization of the strategic leadership outcomes of the polytechnics.

\section{Reference}

[1]. Achua, C.F., \& Lussier, R.N. (2013). Effective Leadership. South-Western Cengage Learning, Canada

[2]. Al-Kahtani, A. H., Abu-Jarad, I., Sulaiman, M., Nikbin, D. (2011). The Impact of personality and leadership styles on leading change capability of Malaysian Managers. Australian Journal of Business and Management Research. New South Wales Research Centre.

[3]. AlKhasaweh, A.L., \& Sahar, M.F. (2013). The impact of leadership styles used by the academic staff in the Jordanian public Universities on modifying students' behaviour: A field study in the Northern Region of Jordan. Canadian Centre of Science and Education. 8(1).

[4]. Biggerstaff. J.K. (2012). The relationship between teacher perceptions of elementary school principal Leadership style and teacher job satisfaction. (Western Kentucky University), Dissertations paper 22, Retrieved from: http://digitalcommon.wku.edu/diss/22.

[5]. Boateng. C. (2012). Leadership Styles and Effectiveness of Principals of Vocational Technical Institutions in Ghana. American International Journal of Contemporary Research. 2 (3).

[6]. Buchanan, D. \& Huczynski, A. (2004) Organisational Behaviour: An Introductory Text, 5th ed., Harlow: FT/Prentice Hall

[7]. Clark, R., Hartline, M. \& Jones, K. (2009). "The effects of leadership style on hotel employees commitment to service quality", Cornell Hospitality Quarterly, 50(2), 209-231.

[8]. Dulewicz.V., \& Higgs.M. (2003). "Leadership at the Top: The Need for Emotional Intelligence in Organizations", The International Journal of Organizational Analysis, Vol. 11 Iss: 3, pp.193 -210

[9]. Government of Ghana.(2007). Polytechnic Act PNDC Law 321(Amendment Act 745 2007).

[10]. Goleman, D. (1998). Working with Emotional Intelligence. New York: Bantam Books.

[11]. Goleman, D. (2000). Leadership that gets results. Harvard Business Review, 79(2), 78-87.

[12]. Goleman, D. (2000). What makes a leader? Harvard Business Review. Harvard Business School Publishing Corporation.

[13]. Gonos. J. \& Gallo. P. (2013). Model for Leadership Style Evaluation. Management. 18(2). pp. 157-168

[14]. Handy, C.B. ((1982). Understanding organisations. London:Penguin.

[15]. Hersey, P., Blanchard, K.H., \& Johnson, D.E. (2009). Management of Organizational Behaviour: Leading Human Resources (9 Ed.) Prentice-Hall, New Jersey.

[16]. Hughes, R.L. \& Colarelli Beauty, K. (1999). Becoming a strategic leader your role in organisation enduring success. The centre for creative Leadership, Jossey Bass, San Francisco.

[17]. Iddrisu, S., Alhassan, E., and Kinder, T. (2014). Educational Reforms and the Role of Polytechnic Education in the Socio- economic Development of Ghana. Africa Development and Resources Research Institute (ADRRI) Journal, 11(2), 29-52.

[18]. Jeremy, M., Melinde, C. \& Ciller, V. (2012). Perceived Leadership Style and Employee Participation in a Manufacturing Company in the Democratic Republic of ongo. African Journal of Business Management. 6(15): 5389-5398.

[19]. Juras, A. (2010). Traits, skills and Leadership styles of managers in Croatia firms. Ekonomski fakultet Sveucilistau Splitu.

[20]. Keiritnar, R., \& Kinicki, A. (2010). Organizational Behaviour ( $9^{\text {th }}$ ed.) Boston, McGraw Hill Irwin.

[21]. Khan, V., Hafeez, M. H., Rizvi, S. M. H., Hasnain, A., and Mariam, A. (2012). Relationship of leadership styles, Employees, commitment and organizational performance. (A case study on Customer Support Representatives). European Journal of Economics, Finance and Administrative Sciences. EuroJournals, Inc. (49).

[22]. Leban, W. \& Zulauf, C. (2004). Linking emotional intelligence abilities and transformational leadership styles. The Leadership and Organisations Development Journal. Emerald Group Publishing Limited.

[23]. Lewin, K., Lippitt, R., \& Whilte, R.K. (1939). Patterns of aggressive behaviour in experimentally created social climates. Journal of Social Psychology. 10: 271-301.

[24]. Mujtaba. B. G. \& Isomura. K. (2012). Examining the Japanese Leadership Orientations and their Changes. Leadership and Organisational Development Journal. 3(4). Pp.401-420.

[25]. Nanjundeswaraswamy T. S. \& Swamy. D. R. (2014). Leadership Styles. Advances in Management. 2 (3).

[26]. Nastase, M. \& Barbu, M. (2011). "Leadership and gender differentiation", Review of International Comparative Management, $12(3), 455-460$.

[27]. Nahavandi, A. (2002). The art and science of leadership (3rd ed.). Upper Saddle River, nj: PrenticeHall

[28]. Oladipo. K. S., Jeffrey. L. D., Jamilah. O., Abu. D., Adekanye. T. (2013). Leadership Style and Job Satisfaction among Employees in Small and Medium Enterprises. International Journal of Business and Management. 8(13). Canadian Centre of Science Education.

[29]. Ramkissoon, A. (2009). A preliminary investigation of the applicability of suitable leadership in other cultures. International Journal of Business Strategy. International Academy of Business \& Economics (IABE, USA).

[30]. Robbins, G., and Coulter, M. (2009). Management $\left(10^{\text {th }}\right.$ ed) Pearson Prentice Hall. In Futah, S.

[31]. M. and Al-Khasawneh, A. L. (2013). The Impact of Leadership styles used by academic staff in the Jordanian Public Universities on Modifying Students' behaviour: A field sty in the Northern Region of Jordan. Canadian Centre of Science Education. International Journal of Business Management, $8(1)$.

[32]. Robbins, S.P. \& Coulter, M. (2009). Management $\left(10^{\text {th }}\right.$ ed) Pearson Prentice Hall.

[33]. Salman, Z., Riaz, A., Saifullah, M. and Rashid, M. (2011). Leadership styles and employee performance. (A case study of Shakarganj Mills Limited. Jhang Pakistan. Interdisciplinary journal of Contemporary Research in Business. Institute of Interdisciplinary Business Research. 3(6).

[34]. Seshie, P.O. (2011). Theory for corporate leadership development: Theoretical foundation for organizational leadership i

[35]. Stogdill, R.M. \& Coons, A.E (1957). eds. Leader behaviour. Its description and measurement. Ohio State University Bureau of Business Research. Columbus.

[36]. Tangpinyputtikhun, T. \& Tiparos, K. (2011). A study of Congruence of the behaviour of followers fit with leadership style that affect work performance. Journal of Academy of Business and Economics. International Academy of Business and Economics (IABE). Vol. 11.

[37]. Trottier, T., Van Mart, M., \& Xiao Hu (2008). Examining the Nature and Significance of leadership in Government Organizations. Leadership in Government Organizations. Public Administration Review.

[38]. VanVactor, J.D. (2012). Collaborative leadership in the management of healthcare. Journal of Business Research, 65, 555-561. 
[39]. Voegtlin et al. (2012). Responsible Leadership in Global Business: A new approach to Leadership and its multi-level outcomes. Journal of Business Ethics, 105(2), 1-16.

[40]. Wang, J., Lee-Davis, L., Kakabadse, N.K., \& Xie, Z. (2011). Leader characteristics and styles in the SMEs of the People's Republic of China during the Global Financial Crisis. Strategic Change. John Wiley \& Sons Inc. DOI:10.1002/jsc.882.

[41]. Yamane, T. (1973). Statistics: An Introductory Analysis. 2rd ed. New York : Harper and Row

[42]. Johnson, R.E., Chang, C.H., \& Yang, L. Q. (2009). Commitment and Motivation at work. The relevance of employee identity and regulatory focus. Academy of Management Review. 35(2): 226-245.

[43]. Yukl, G. (2006). Leadership in Organisations ( $8^{\text {th }}$ ed.) New Jersey, Pearson Prentice Hall. 